UDC 327:061.[1EU:061.2]:32(560):314.151.3-054.73(569.1)

\author{
Irrera D. \\ Prof., Dr (Political Sciences) \\ Department of Political and Social Sciences \\ University of Catania \\ Via Vittorio Emanuele 49, 95131, Catania, Italy \\ E-mail: dirrera@unict.it \\ ORCID iD: https://orcid.org/0000-0003-1572-2922 \\ DOI: http://dx.doi.org/10.18524/2304-1439.2019.32.173853

\section{NGOs AND THE EU REGARDING THE MANAGEMENT OF SYRIAN REFUGEES IN TURKEY ${ }^{1}$}

Based on the assumption that there are different approaches to the activities of non-governmental non-governmental organizations (NGOs) implementing migrant and refugee policies, the author attempts to answer the following questions: - What impact can NGOs have on EU Member States and on migrants and refugees? - Can long-term and sustained experience in emergencies have such an impact? - Does the work of the NGO within the Fund, along with international agencies and the Red Cross, affect EU policy and relations with Turkey in this policy area? The article is divided into three parts. In the first, non-state actors (NGOs) are analyzed within the framework of theoretical studies on migration and humanitarian strategy. The second one deals with the EU's relations with Turkey through the aforementioned lenses. Third, empirical funding data provided by ECHO to non-governmental organizations is used to evaluate arrangements and developments. The data is used to evaluate future prospects. The article notes that the events of the last decade have called into question the values and practices of the EU. It is shown that European NGOs seek to play an executive role in the implementation of EU humanitarian projects for Syrian refugee camps in Turkey. The author concludes that non-state actors remain important but controversial actors in the implementation of EU policy. NGOs have different approaches and their ideological and political differences are reflected in their relationship with political power. The author emphasizes the increasing critical attitude towards the lack of EU solidarity, especially in matters of emergency management interventions carried out by non-state SAR operations. Thirdly, the author points out that, in parallel with practices that typically replace states and the EU, NGOs support a consolidated partnership with ECHO. The growing role of non-state actors in managing sensitive global crises such as migration and refugees has been demonstrated. The risk for the EU is the loss of the chance to manage the crisis as a laboratory and a model of functional coordination that can be implemented and secured in the rest of the world system.

Key words: NGOs, migrants, refugees, European Union, Turkey.

\footnotetext{
1 The research leading to these results has received funding from the University of Catania Research Plan 2016-2018, within the project on «The Italian policy on asylum and visa among internal and external dynamics. Principles, actors, processes».
} 
Basement of the Study. The EU, over the last decade, has experienced very difficult times, marked by financial instability, institutional frictions, the impact of terrorist attacks and, ultimately the need to face migrants and refugees flows. The EU migration governance has been characterized by controversial summits, military attempts to save people in the Mediterranean and along the Balkan route and to mitigate the radical views of the governments of several member states. The agreement signed with Turkey, titled the Refugee Facility, is the last step of this process. Basically, it is a way to divert irregular migrants crossing from Turkey into the Greek islands and leave to the direct management of the Turkish government. The European NGOs have been asked to play an executive role, with the implementation of the agreement, as well as implementing the EU humanitarian projects towards the Syrian refugee camps in Turkey. After few years from its entry into force, this article aims to assess its impact, focusing on the role exerted by NGOs, acting at the EU level.

Analysis of Researches. GOs actions are analyzed within the development of EU strategy and policies, through the different phases that followed one another in the period starting from 2011 until present (F. Attina, 2018 [4, p. 49-70]). At the beginning (2011-2013), the response has been conventional, and almost based on the lack of recognition of the crisis and need to change the existing EU's policy towards migration. This policy is represented by the Commission's 2011 Communication Global Approach to Migration and Mobility (GAMM), approved by the Council. In this period, and until autumn 2014, the launch of Mare Nostrum operation represented a significant response to the humanitarian crisis, However, it was also the first demonstration of the need (on the EU's part) to build a set of tools and capacities grounded on common solidarity and responsibility. The high price of such common commitment produced, in this phase (Nov. 2014-Sept. 2015), a substantial shift into EU performance. Subsequently, a more comprehensive approach was adopted, through the end of Mare Nostrum and the launch of Triton mission, with a structured set of Search and Rescue (SAR) tools and tasks. The last period, from October 2015 to present is a return back to the protection of external borders and the reintroduction of barriers, the evident failure of any solidarity approach and the rise of populist policies in several member countries. The approach shown by NGOs followed this development and was particularly visible and relevant since the end of 2014, when several organizations started to get involved directly in the Mediterranean, through Search and Rescue Operations (SAR). Whereas, many others focused on supporting projects in favor of refugees in the framework of the Facility (D. Irrera, 2016 [29, p. 20-29]; P. Cuttitta, 2017 [12, p. 1-29]). Thus, based on the assumption that both performances represent different faces of a strong commitment NGOs have implemented in the migrants and refugees' policies (at national and regional level), the article aims at answering to these questions:

- What are the impacts that NGOs can exert on member states and EU policies towards migrants and refugees?

- Can such impact be able to produce long-term and established practices beyond the emergency phase? 
- Is the work currently conducted by NGOs within the Facility, next to international agencies and Red Cross, influencing the EU approach and the relations with Turkey in this policy field?

The article is divided into three parts. First, non-state actors, and specifically NGOs, are analyzed within the theoretical studies on migration and within the European aid and humanitarian strategy, to stress their roles and approaches and understand their relevance in such analysis. Second, relations with Turkey and the agreement are investigated through the abovementioned lenses. Third, empirical data on funding allocated by ECHO to NGOs are used to assess the agreement and the current developments. Lastly, theoretical reflections and data are used to assess current trends and raise future perspectives.

1. Non-state actors and human mobility. International political phenomena like globalization, economic and social inequalities and demographic changes have produced an impact on human mobility and have advanced the increasing movements of international people. Moreover, masses of people are forced to escape, because of local conditions, that is to say, political failure, institutional instability, civil war, and the effects of organized smugglers activities. Regional and supranational institutions had to adjust their policies and strategies to such transformations and conditions. However, they faced, a somewhat strong reticence, particularly on the part of states (F. Adamson, 2006 [1, p. 165-199]; S. Castles, 2010 [10, p. 1565-1586]; A. Betts, 2011 [6]). Although international migration is not at all a recent phenomenon, the discourse surrounding contemporary patterns (the effects of economic crisis and the unexpected amount of people crossing the Mediterranean or the Balkans, the fear of ISIS infiltration) has become increasingly preoccupied with its relation to security and the danger of terrorism (D. Irrera, 2016 [29, p. 20-35]).

The events which have affected the Mediterranean and the Balkan region in the last decade have confirmed that Europe is one of the preferred regions of immigration. However, these events also demonstrated the lack of capacity by European governments and EU institutions to manage the political and social implications of mobility (Kahanec and Zimmerman, 2016). Therefore, debates concerning migrants, asylum seekers and refugees have been dominated by the security paradigm. On the one hand, a traditional policy approach emphasizes asylum as a human rights question to be managed with human rights tools and practices. On the other, mobility is more frequently framed as a security issue, dealing with lives to be rescued, political refugees to be protected, asylum seekers to be managed and integrated into European societies (A. Geddes, 2003 [19], 2008 [20]; A. Glorius, I. Grabowska-Lusinska, and A. Kuvik, 2014 [21]).

Moreover, the security paradigm has been part of migration studies for several years. Security practices pervade communities and their way of living, by shaping a potential response to those which are perceived and defined as potential threats to the status quo (J. Huysmans, 2000 [27]; S. Leonard, 2010 [33]; D. Bigo, 2011 [9]; A. Lazaridis and F. Khursheed, 2015 [31]). Likewise, 
in the case of the EU, the member states practices and policies have been designed and shaped over the years, throughout the integration process. Thus, creating a common European security culture other than a common set of values and beliefs (C. Meyer, 2006 [35]; M. Gariup, 2017 [18]).

The role of non-state actors as a factor of contestation, change, or integration of public policies on migration is already part of the scholarly debate (A. Bieler, R. Higgott, and G. Underhill, 2004 [8]; T. Risse, 2007 [40]; M. Beisheim and A. Liese, 2014 [7]). At the same time, civil society organizations, and in particular, NGOs have played a pivotal role in the assistance to migrants at all levels. Traditional tasks, which are in favor of development have been integrated by more active involvements. For instance, the SAR interventions in the Mediterranean, as a result of the changes which have been observed during more recent events. Arguably, this combination deserves further investigations, and it can also be viewed as a part of the broader and still controversial debate of non-governmental engagement in political participation, representation, and democratization of the decision-making processes, at all levels (S. Ahmed and D. M. Potter, 2006 [2]; K. Reimann, 2006 [38]; D. Irrera, 2013 [30]).

Sociologists and International Relations scholars have widely debated the relationship between civil society organizations and states in a sensitive policy field, like migration. In particular, scholars have observed that civil society has responded in very different ways in addition or in reaction to state policies, producing various forms of support, aid, and supply of basic services (Fernandez-Kelly, 2012; M. Ambrosini, 2017 [3]).

If certain services are not granted to people in need, insecurity can rise. Thus, the sense of discrimination of minorities could then increase, and the moral legitimacy of public institutions can be weakened - that is, their capacity to obtain the loyalty of citizens as bearers and defenders of basic human rights. Therefore, they often try to provide necessary services, not directly, but by delegating these tasks to NGOs or by indirectly facilitating or funding their activities. In the specific case of the EU humanitarian action, for example, the relations with NGOs have been strongly developed over the years through the aid programs and within ECHO activities. At the same, they have developed and strengthened direct relations with member states, in a more or less coordinated manner (D. Irrera, 2018 [28]).

Even in the migration policy, European NGOs have consolidated an established set of formal and informal consultations with institutions and governments, which usually works properly. NGOs are generally considered as useful actors, informed about current initiatives and able at least to enrich the agenda with their own proposals.

Generally, the impact of NGOs on EU policies is difficult to measure. Moreover, it is even more fragmented and controversial, in migration policies, given the dominant roles of Member states and the strong influence of intergovernmental preferences. Therefore, the majority of NGOs have continued to work in the traditional field of assistance, by developing a wide variety of approaches. Some NGOs had initially worked on favoring the end of legal 
immigration and promoting the growing dominance of control and admission issues by shifting their focus to integration, anti-racism, or multiculturalism (A. Warleigh, 2001 [44]; V. Guiraudon, 2003 [22]). Similarly, the NGOs, which developed a strong focus on asylum recognize that migration is as an emerging alternative mode of entry into Europe. Moreover, and that the questions relating to the assessment of migration needs and the design of migration systems deserve close non-governmental attention. This action turned into another traditional role of non-state actors, that is to say, the watchdog of EU policies and member states behaviors and the consequent production of documents, position papers and press releases which express critical views (S. Sterkx, 2008 [31]; A. Menz, 2011 [34]).

The most interesting debate came regarding recent EU initiatives, border controls through military and civilian operations. In October 2013, the arrival of un-wanted people via the sea to Europe dramatically demonstrated there was a real humanitarian crisis in the Mediterranean (which, could not be simply denied) and forced to the Italian government to launch of Mare Nostrum (MN). It was established to tackle the dramatic increase of migratory flows during the second half of the year and consequent tragic ship wreckages off the island of Lampedusa. According to the Italian position, Mare Nostrum was complying to the norms of the international laws like those on the Search and Rescue of distress persons at sea, and the humanitarian values, endorsed by many international treaties and state constitutions (F. Attina, 2018 [4]). Additionally, MN was also coherent with a 2004 national law, since it empowered the Migration Flows Control (CFM) activities carried out within the Italian Navy operation Constant Vigilance (M. Tazzioli, 2016 [42]).

The initial discussion regarding the efficacy of SAR and the pertinence of their use has opened a contentious debate. According to reports, NGOs consider that border controls are a form of military war against migrants. Mare Nostrum was provided with ample powers and rescued over 100.000 people in the Central Mediterranean. However, NGOs expressed very critical views, in line with documents produced by UN agencies, like IOM and UNHCR. They restarted to criticize the lack of solidarity and common approach and accused Frontex operations to be excessively militarized and not driven by a human approach. Besides, such an approach was exacerbated by the launch of Triton, a Frontex operation, which was provided with specific (but limited if compared to Mare Nostrum) search and rescue tasks. Triton was officially presented, in November 2014, as not being a replacement of Mare Nostrum, but as a new effective part of a comprehensive strategy, aiming at saving lives, protecting refugees, and managing the root causes. However, according to the NGOs, it was not enough, which showed the same concern of other UN agencies, especially if compared to Mare Nostrum performances. The comprehensive approach, as developed by the EU to manage this acute phase, was mainly based on the recognition of exceptional circumstances (which caused the waves of migrants) and on the need to coordinate efforts among EU (Triton) and member states (F. Attina, 2018 [4]). NGOs, then, decided to become more active (A. Hugo, 2014 [26]; F. Trauner, 2016 [43]; J. Jeandesboz, and P. Pallister-Wilkins, 2016 [23]). 
2. The Refugee Facility and EU humanitarian policy. The humanitarian duties requested to coastal states and other state members, to come together in solidarity, which turned into a mixture of reluctancy, forced reactions and self-protective closeness. Although some states continued to remain engaged in the Central Mediterranean very actively and contributed to mitigate the effects of the crisis, some (many others) remained far from any EU collective efforts and more or less openly refused to cooperate. Namely, in the management of masses of Syrian refugees who were trying to reach eastern Europe through the Balkans.

NGOs started to be more publicly critical and denounced the inability of the EU to properly evaluate the humanitarian crisis in the Mediterranean as well as its member states to change current policies. Particularly, the critics were not only focused on the rescuing capabilities, but also on the way's migrants were perceived and rejected. The Refugee Facility was then identified as the potential tool for mitigating the humanitarian emergency along the Balkans, by accommodating some member states' preferences (L. Adam, 2016 [5]; K. Rygiel, F. Baban, and S. Ilcan, 2016 [39]).

The agreement, which was signed with the Turkish government in February 2016 intended to produce one main result, that is to say, to promote the return of new irregular migrants crossing from Turkey into the Greek islands and to favor the exchange. Therefore, for every Syrian returned to Turkey, another Syrian was expected to be resettled from Turkey to the EU. The operation cost a total of $€ 6$ billion ( $€ 3$ billion for 2016-2017 and $€ 3$ billion for 2018-2019) to be paid by EU to Turkey for delivering supplementary humanitarian assistance to refugees in the country. The entire process was expected to cohere with the EU vulnerability criteria and to strive to meet the humanitarian conditions in Syria along the Turkish borders. In particular, this guarantee, was assured by the composition of the Steering Committee of the Facility itself, made of Member States. The list of priorities on which the budget was allocated included humanitarian assistance; education; migration management; health; municipal infrastructure; and socio-economic support (EU Commission, 2015 [15]). The Commission's decision emphasized the commitment by the Government of Turkey to political and financial support in designing a proper response to the regional refugee crisis, collaboratively with the Directorate General of Migration and Management (DGMM) and local authorities. Namely, the DGMM remained responsible for matters pertaining to refugees and asylum seekers, that is to say, the registration of Syrian refugees under Temporary Protection, the Turkish National Disaster Management Authority (AFAD), the Turkish Red Crescent (TRC) were expected to work with other humanitarian actors to assist refugees camps. Gradually, in the later months, the coordination of all local government bodies and institutions in all refugees' affairs was assigned to AFAD.

The mechanism under which the Facility was conceived and structured was based on a sort of strategic partnerships between international NGOs, local Turkish civil society organizations and competent Government agencies for 
developing capacities and offered the appropriate key social services for the refugees hosted in Turkey.

Arguably, mechanisms like this look to be coherent with the EU humanitarian aid policy, as it has been designed and developed over the past three decades. Moreover, such policy has been conceived as one of the most visible expressions of the EU solidarity, as it is shaped on universal humanitarian principles as well as rules and practices established on a global level. The EU aims at exerting a role of international actor to manage crises, to assist people in distress, and to provide security and stability in the neighborhood and in the world. These ambitious plans have been the premise for establishing a set of tools and practices has gradually become more sophisticated and multilayered. The Directorate General for Humanitarian Aid and Crisis Management (DG ECHO), updated and upgraded (to some extent) in 2010, has coordinated and ensured the delivery of all kind of aid to third countries. Coherently with EU common values, member states have basically sustained such policy, investing their resources and pursuing national agendas accordingly ( $J$ Orbie, P. Van Elsuwege and F. Bossuyt, 2014, [36]; C. Dany, 2015 [13]; D. Irrera, 2018 [28]). At the same time, since ECHO does not act on the ground, but provides mandate and resources to its partner organizations, the role of nongovernmental actors has increased and diversified. Over the years, NGOs have played important tasks in implementing ECHO agenda, favoring the efficient and useful application of projects, promoting the legitimacy of the external intervention and, most importantly, monitoring the EU and member states performances.

Since 2010, ECHO competencies, activities, and budgets have been expanded and applied to additional and more sensitive policy fields, like assistance to migrants and refugees and internally displaced persons (IDP) in conflict zones, implying a considerable diversification of actions and projects.

According to the general expectations, ECHO mechanism was intended to manage the situation in Turkey and develop a proper strategy under the Facility, targeting basic needs and protection, coherently with values, practices, and norms developed within the humanitarian aid policy. In particular, ECHO was asked to follow a needs-based approach, which could consider and will consider a «one-refugee» approach. Besides, that is to say, the provision of assistance to all persons of concern based on equivalent or equal vulnerability criteria regardless of nationality or status (EU Commission 2017 [17]). The main issue was dealing with the EU budget allocated to the ECHO mechanism in migration-related projects. Since such projects cannot be covered with a central EU fund, funding instruments are established under other EU policy fields, such as justice and home affairs, neighborhood and enlargement policy and humanitarian aid policy (L. Den Hertog, 2016 [14]).

In all abovementioned policies, the process of establishing, programming, managing and implementing EU funding instruments implicate a complex set of interactions between very different actors, both intergovernmental (Commission Directorate Generals, agencies, the European Parliament, international organizations) and non-governmental, particularly NGOs. The humani- 
tarian aid policy provides a paradigmatic example of how different actors interact, clash, and negotiate according to their own interests and priorities. However, the funding background appears extremely fragmented and confusing, even when it is applied to more sensitive policy fields and complemented with new and additionally funding instruments, like the Refugee Facility, for balancing arrangements with third countries and regions (L. Den Hertog, 2016 [14]).

ECHO started to manage the Facility by coordinating several external financing instruments, namely, the Council Regulation (EC) No 1257/96 concerning the humanitarian aid (HUMA), the European Neighbourhood Instrument (ENI), the Development Cooperation Instrument (DCI), the Instrument for Pre-Accession Assistance (IPA II) and the Instrument contributing to Stability and Peace (IcSP), and above all, the EU Regional Trust Fund in Response to the Syrian Crisis (EUTF) (EU Commission 2017), which constitute the development of the so-called Humanitarian Implementation Plan (HIP) for Turkey (EU Commission 2016 [16]).

Although part of the mechanism, NGOs have been very critical towards the rationale of the EU funding for migration. As Den Hertog points out, the 'root causes' and 'conditionality' approaches have become dominant in the EU external intervention. The 'root causes' approach intended to tackle the drivers of irregular migration and to limit them, while the 'conditionality' connects external funding to third country cooperation on border management and fulfilling specific criteria. As highlighted in many NGOs reports, both viewpoints imply distortions, make it hard to achieve the real objectives. Both approaches are difficult to coordinate and implement in reality, particularly given the level of fragmentation in funding and are based on a partial understanding of the effects of funding on migration flows. The additional danger is that third countries may consider migration as increasing leverage to obtain EU funding, and, in the long term, this may affect the work done in the development and humanitarian field.

As seen in the previous paragraph, spring 2015 marks a shifting process in the NGOs approach towards the migration and refugee crisis in Europe and its most visible and dramatic manifestations. Non-governmental SAR operations in Central Mediterranean launch a more active and innovative approach, extremely critical towards the government and EU lethargy. Steps like the Facility are considered as mere anesthetic solutions. However, in parallel, many of the other NGOs continued with their well-established role of an implementing actor and started cooperating with Syrian and Turkish NGOs, by working in partnership with the EU and other international humanitarian aid agencies, for providing relief within the Facility.

3. The Refugee Facility, ECHO, and NGOs and EU humanitarian policy. The EU humanitarian aid policy has developed over the decades as a complex mechanism, in which EU institutions, member states, NGOs and private actors interact and negotiate according to different preferences and interests, but coherently with common values and practices. Besides, the application of such a mechanism to additional and more sensitive policy fields have 
fragmented its functioning, particularly from a financial perspective. In all official documents, the Facility is labeled as a 'coordination mechanism', emphasizing the fact that interactions among various actors are partly governed by formal procedures but more often takes place informally and the overall funding background is based on the continuous search for more flexibility. Although very critical towards this complicated mechanism (which underestimates many social issues), NGOs have played a relevant role and contribute to balance the political constraints which member states continuously raised.

As a specific multi-actor platform, the Facility has been paradigmatic in the inclusion of stakeholders. Since DG ECHO works based on agreements with partners to implement projects, the chances for external entities, both international organizations, and NGOs to be the final implementers, but also to influence the priority-setting for funds, have hugely increased (L. Den Hertog, 2016 [14]).

Under the Facility, the main beneficiaries of the EU funds have been major international humanitarian organizations, like the International Organization for Migration (IOM), and UN-related agencies, in close cooperation with local Turkish partners, hybrid organizations like the International Federation of Red Cross and Red Crescent Societies (IFCR) and, obviously, international NGOs in partnerships with Turkish and Syrian ones. Cooperation has also been facilitated by the lack of real and open competition in assigning the projects, since it was limited to those organizations which were already linked with the EU institutions (L. Adam, 2016 [5]).

Furthermore, an empirical investigation on the funds allocated to projects under the Facility cannot be completed, due to the limited amount of time. However, the reports made by EU agencies and data provided by ECHO allow for some preliminary considerations to be made, particularly with the role exerted by NGOs. Figure 1 presents an overview of sums which have been given and effectively disbursed to different implementing actors since the entry into force of the mechanism until June 2018.

According to the formal provisions, the additional funding was expected to be allocated by ECHO to respond to the needs of out-of-camp refugees, in urban settings and Southern governorates, and along the migration route at Aegean coastal areas. Therefore, projects primarily focusing on these priorities, and specifically on protection, health, and education have been supported and financially sustained (EU Commission, 2016 [16]).

The data in Fig. 1 demonstrates that ECHO has already disbursed significant funds (almost 1.94 billion EURs) - in the provision of services through projects that are implemented by its partners. Additionally, the NGOs firmly maintain their implementing role, even though international organizations and UN agencies represent the most important partners for ECHO. They have received more contracts, and appear very active in the country, even more than the Red Cross. Another interesting element, resulting from data, is the limited difference regarding the contracted and disbursed sums, which reveals a very prompt capacity to manage funds. 


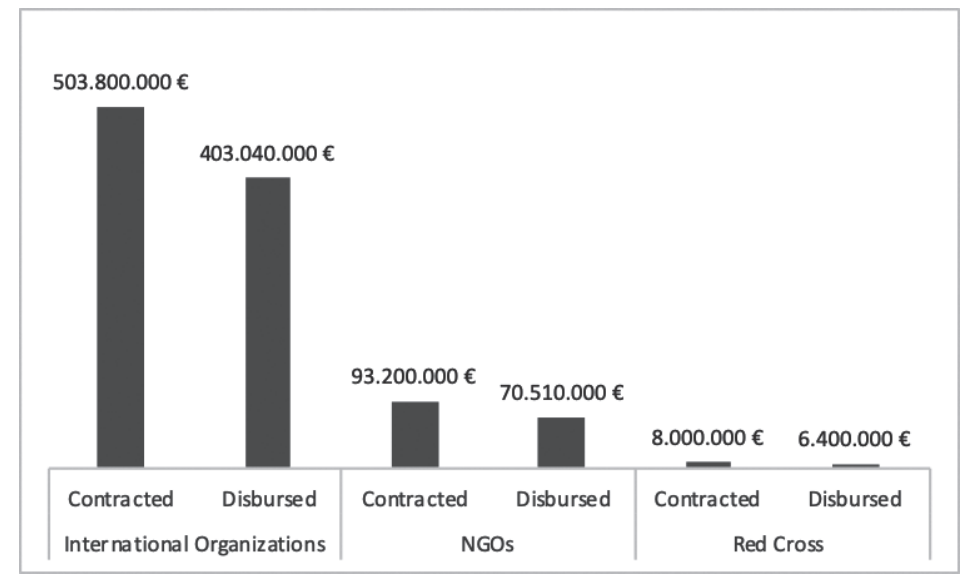

Fig. 1. Projects supported under the Facility (June 2018) Source: ECHO, 2018

Although the first official reports have identified some specific problems. Particularly, the limited capacity of ECHO partners to operate at scale in strategic partnerships with Syrian and Turkish NGOs and the Government of Turkey, as well as the inconsistent regulatory framework regulating the task of international humanitarian NGOs in the country (EU Commission, 2016 [16]). However, these issues, the presence, and work of organizations like Medecins $\mathrm{du}$ Monde, Mercy Corps, World Vision, is massive and constant. Although its controversial political nature and its impact on an extremely vague EU migration strategy, the Facility framework tends to replicate the mechanisms and approaches which have developed within the EU humanitarian aid policy and is strongly influenced by non-governmental actors.

From an NGOs perspective, two main implications can be observed. On one hand, the Facility confirms the strong relations with ECHO and the role of implementing actor that has been consolidated over the years and has contributed to exert a stronger influence on policies, practices and on the allocation of funds. On the other hand, contributing to this framework may result into a sort of acceptance and legitimization of its rationale and objectives, by putting some NGOs in a condition totally different from those operating SAR in the Mediterranean. Thus, apart from affirming the relevant role of non-state actors, the current migration and refugees crisis produces a wide variety of approaches and performances, both traditional and innovative.

Conclusion. The events which have occurred in the last decade have seriously challenged the EU values and practices. Undoubtedly, the migration crisis must be managed, and the effects of its humanitarian dimensions must be mitigated. Likewise, the EU needs to simultaneously tackle human trafficking, defend human rights at an international standard, and continue playing the role of peace and stability provider, without disappointing its member states' preferences and interests. The agreement signed with Turkey, the Refugee Facility, has represented a way to divert irregular migrants crossing 
from Turkey into the Greek islands, and has been left to be managed directly by the Turkish government. Moreover, under this framework, European NGOs have been asked to play an executive role, in implementing the EU humanitarian projects for the Syrian refugee camps in Turkey.

Therefore, this article aims to serve as a preliminary analysis of such impact, in parallel to the different approaches and performances developed by some NGOs, particularly those operating SAR operations in the Central Mediterranean. Although the political nature of the Facility is controversial, it has already produced some effects. Namely, effects concerning the funds contracted and disbursed to support projects implemented in Turkey by ECHO's partners. The reports that have already been issued by the EU agencies and the data provided by ECHO allow some reflections, allow some reflections. Furthermore, it is evident that this topic still requires further research, besides more empirical investigations to reach a conclusive viewpoint.

First, similar to several other sensitive policy fields, non-state actors remain relevant and controversial. Likewise, within the vast NGO community, different approaches, ideological and political divergences are reflected in the relationship with political power. At the EU level, NGOs have been dominated by the need to cope with the security paradigm, besides protecting and emphasizing the human dimension against the discourse.

Second, a growing involvement in the crisis and a more critical attitude towards the lack of EU solidarity has been produced. It has complemented the traditional assistance to development and social integration, with a series of more active interventions, particularly associated to the emergency management phase, which culminated in non-governmental SAR operations. Third, parallel to the practices which tend to substitute to states and the EU, NGOs have also confirmed and maintained their consolidated partnership with ECHO. Besides their role in implementing the provision of basic services and assistance to Syrian refugees in Turkey.

Although it may appear antithetical, both performances are different sides of the same phenomenon. The role is unavoidable for non-state actors in the management of global sensitive crises, like the migration and refugees. The main risk for the EU is to miss the chance to manage the crisis as a laboratory and to develop a model of functional coordination, which may be pioneered and consolidated in the rest of the global system.

\section{References}

1. Adamson, F. B. "Crossing borders: international migration and national security». International security. 31(1) (2006): 165-199.

2. Ahmed, S. and D. M. Potter. NGOs in international politics. Vol. 48. Bloomfield, CT : Kumarian Press, 2006.

3. Ambrosini, M. «Why irregular migrants arrive and remain: the role of intermediaries». Journal of Ethnic and Migrations Studies. 43 (11). (2017): 1-18.

4. Attina, F. "Tackling the migrant wave: EU as a source and a manager of crisis». Revista Espacola de Derecho Internacional., 70 (2) (2018): 49-70.

5. Adam, L. "The refugee card in EU-Turkey Relations: a necessary but uncertain deal». Istituto Affari Internazionali. 2016. 
6. Betts, A. (eds.) Global migration governance. Oxford: Oxford University Press. 2011.

7. Beisheim, M. and A. Liese Transnational partnerships: effectively providing for sustainable development? London: Springer, 2014.

8. Bieler, A., Higgott, R. and G. Underhill (eds.), Non-state actors and authority in the global system. London: Routledge. 2004.

9. Bigo, D. «Globalisation and Security». In Amenta E., Nash K. and A. Scott (eds.) The New Blackwell Companion to Political Sociology'. London : Blackwell, 2011.

10. Castles, S. «Understanding global migration: A social transformation perspective». Journal of ethnic and migration studies. 36 (10) (2010): 1565-1586.

11. Caviedes, A. «European Integration and the Governance of Migration». Journal of Contemporary European Research. 12 (1) (2015): 552-565.

12. Cuttitta, P. «Repoliticization Through Search and Rescue? Humanitarian NGOs and Migration Management in the Central Mediterranean'». Geopolitcs. (2017): 1-29.

13. Dany, C. «Politicization of Humanitarian Aid in the European Union». European Foreign Affairs Review. 20 (3) (2015): 419-437.

14. Den Hertog, L. "Money talks: Mapping the funding for EU external migration policy». CEPS Paper in Liberty and Security in Europe. Brussels. 95 (2016): 12-25.

15. EU Commission (2015), Decision on the coordination of the actions of the Union and of the Member States through a coordination mechanism - the Refugee Facility for Turkey, Decision $\mathrm{C}(2015) 9500$ of 24.11 .2015 .

16. EU Commission (2016), ECHO Humanitarian Implementation Plan (HIP) for Turkey, Ref. Ares(2016)2580378-03.06.2016 > URL: http://ec.europa.eu/echo/sites/echo-site/files/hip_ turkey_2016.pdf

17. EU Commission (2017), Communication from the Commission to the European Parliament and the Council, First Annual Report on the Facility for Refugees in Turkey, COM/2017/0130 final

18. Gariup, M. European security culture: language, theory, policy. London: Routledge, 2017.

19. Geddes, A. Immigration and European integration: beyond fortress Europe? Manchester: Manchester University Press, 2008.

20. Geddes, A. The politics of migration and immigration in Europe. Sage, 2003.

21. Glorius, A., Grabowska-Lusinska I., and A. Kuvik (eds) Mobility in transition: Migration patterns after EU enlargement. Amsterdam: Amsterdam University Press, 2014.

22. Guiraudon, V. «The constitution of a European immigration policy domain: a political sociology approach». Journal of European public policy. 10 (2) (2003): 263-282.

23. Jeandesboz, J. and P. Pallister-Wilkins. «Crisis, routine, consolidation: The politics of the Mediterranean migration crisis». Mediterranean Politics. 21 (2) (2016): 316-320.

24. Kahanec, M. and K. Zimmermann. (ed.) Labor migration, EU enlargement, and the great recession. Berlin: Springer, 2016.

25. Hampshire, J. «European migration governance since the Lisbon treaty: introduction to the special issue». Journal of Ethnic and Migration Studies. 42 (4) (2016): 537-553.

26. Hugo, A. «Mare Europaeum? Tackling Mediterranean Migration». European Union Institute for Security Studies. 25 (2014).

27. Huysmans, J. «The European Union and the securitization of migration». Journal of Common Market Studies. 38 (5) (2000): 751-77.

28. Irrera, D. EU emergency response policies and NGOs. Basingstoke: Palgrave, 2018.

29. Irrera, D. «Migrants, the EU and NGOs: The 'Practice' of non-governmental SAR operations». Romanian Journal of European Affairs. 16 (3) (2016): 20-35.

30. Irrera, D. NGOs Crisis Management and Conflict Resolution: Measuring the Impact of NGOs on Intergovernmental Organisations. Edward Elgar, Cheltenham, 2013.

31. Lazaridis, A. and W. Khursheed. The securitisation of migration in the EU: debates since 9/11. London: Springer, 2015.

32. Lavenex, S. and F. Jurje. «EU/US Migration Policy Towards Emerging Countries: Regulatory Power Reversed?» 22 EFA Rev. 2 (1). (2017): 157-175.

33. Léonard, S. «EU border security and migration into the European Union: FRONTEX and securitisation through practices». European security. 19 (2) (2010): 231-254.

34. Menz, A. «Stopping, Shaping and Moulding Europe: Two Level Games, Non state Actors and the Europeanization of Migration Policies». JCMS: Journal of Common Market Studies. 49 (2) (2011) : 437-462. 
35. Meyer, C. The quest for a European strategic culture: changing norms on security and defense in the European Union. London: Springer. 2006.

36. Orbie, J., Van Elsuwege, P. and F. Bossuyt. «Humanitarian Aid as an Integral Part of the European Union's External Action: The Challenge of Reconciling Coherence and Independence». Journal of Contingencies and Crisis Management. 22 (3) (2014): 158-165.

37. Pollak, J. and P. Slominski. «Experimentalist but not accountable governance? The role of Frontex in managing the EU's external borders». West European Politics. 32(5) (2009): 904-924.

38. Reimann, K. D. "A view from the top: International politics, norms and the worldwide growth of NGOs'». International Studies Quarterl. 50 (1) (2006): 45-67.

39. Rygiel K., Baban F. and S. Ilcan. «The Syrian refugee crisis: The EU-Turkey 'deal'and temporary protection'». Global Social Policy. 16 (3) (2016): 315-320.

40. Risse, T. «Transnational actors and world politics». In Corporate ethics and corporate governance. Berlin: Springer, 2007: 251-286.

41. Sterkx, S. «The external dimension of EU asylum and migration policy: expanding fortress Europe?» In Europe's global role: External policies of the European Union. 2008: 117-38.

42. Tazzioli, M. «Border displacements. Challenging the politics of rescue between Mare Nostrum and Triton». Migration Studies. 4(1) (2016): 1-19.

43. Trauner, F. "Asylum policy: the EU's 'crises' and the looming policy regime failure». Journal of European Integration. 38 (3) (2016): 311-325.

44. Warleigh, A. «Europeanizing'civil society: NGOs as agents of political socialization». JCMS: Journal of Common Market Studies. 39 (4) (2011): 619-639.

\section{Список використаної літератури}

1. Adamson F. B. Crossing borders: international migration and national security. International security. 2006. № 31 (1). P. 165-199.

2. Ahmed S., Potter D. M. NGOs in international politics. Vol. 48. Bloomfield, CT: Kumarian Press, 2006. 273 p.

3. Ambrosini M. Why irregular migrants arrive and remain: the role of intermediaries. Journal of Ethnic and Migrations Studies. 2017. № 43 (11). P. 1-18.

4. Attina F. Tackling the migrant wave: EU as a source and a manager of crisis. Revista Espacola de Derecho Internacional. 2018. № 70 (2). P. 49-70.

5. Adam L. The refugee card in EU-Turkey Relations: a necessary but uncertain deal. Istituto Affari Internazionali, 2016. $12 \mathrm{p}$.

6. Betts A. (eds.) Global migration governance. Oxford: Oxford University Press, 2011. $368 \mathrm{p}$.

7. Beisheim M., Liese A. Transnational partnerships: effectively providing for sustainable development? London: Springer, 2014. 115 p.

8. Bieler A., Higgott, R., Underhill G. Non-state actors and authority in the global system. London: Routledge. 2004. 320 p.

9. Bigo D. Globalisation and Security. Amenta E., Nash K. and A. Scott (eds.) The New Blackwell Companion to Political Sociology. London : Blackwell, 2011. 496 p.

10. Castles S. Understanding global migration: A social transformation perspective. Journal of ethnic and migration studies. 2010. № 36(10). P. 1565-1586.

11. Caviedes A. European Integration and the Governance of Migration. Journal of Contemporary European Research. 2015. № 12 (1). P. 552-565.

12. Cuttitta P. Repoliticization Through Search and Rescue? Humanitarian NGOs and Migration Management in the Central Mediterranean'. Geopolitcs. 2017. P. 1-29.

13. Dany C. Politicization of Humanitarian Aid in the European Union. European Foreign Affairs Review. 2015. № 20 (3). P. 419-437.

14. Den Hertog L. Money talks: Mapping the funding for EU external migration policy. CEPS Paper in Liberty and Security in Europe. Brussels, 2016. № 95. C. 12-25.

15. EU Commission (2015). Decision on the coordination of the actions of the Union and of the Member States through a coordination mechanism - the Refugee Facility for Turkey, Decision C (2015) 9500 of 24.11.2015. 
16. EU Commission (2016). ECHO Humanitarian Implementation Plan (HIP) for Turkey, Ref. Ares(2016)2580378-03.06.2016. URL: http://ec.europa.eu/echo/sites/echo-site/files/hip_ turkey_2016.pdf

17. EU Commission (2017). Communication from the Commission to the European Parliament and the Council, First Annual Report on the Facility for Refugees in Turkey, COM/2017/0130 final

18. Gariup M. European security culture: language, theory, policy. London: Routledge, 2017. $234 \mathrm{p}$.

19. Geddes A. Immigration and European integration: beyond fortress Europe? Manchester: Manchester University Press, 2008.

20. Geddes A. The politics of migration and immigration in Europe. Sage, 2003.

21. Glorius A., Grabowska-Lusinska I., Kuvik A. Mobility in transition: Migration patterns after EU enlargement. Amsterdam: Amsterdam University Press, 2014. 343 p.

22. Guiraudon V. The constitution of a European immigration policy domain: a political sociology approach. Journal of European public policy. 2003. № 10 (2). P. 263-282.

23. Jeandesboz J., Pallister-Wilkins P. Crisis, routine, consolidation: The politics of the Mediterranean migration crisis. Mediterranean Politics. 2016. № 21 (2). P. 316-320.

24. Kahanec M., Zimmermann K. Labor migration, EU enlargement, and the great recession. Berlin: Springer, 2016. $521 \mathrm{p}$.

25. Hampshire J. European migration governance since the Lisbon treaty: introduction to the special issue. Journal of Ethnic and Migration Studies. 2016. № 42 (4). P. 537-553.

26. Hugo A. Mare Europaeum? Tackling Mediterranean Migration. European Union Institute for Security Studies. 2014. № 25.

27. Huysmans J. The European Union and the securitization of migration. Journal of Common Market Studies. 2000. № 38 (5). P. 751-77.

28. Irrera D. EU emergency response policies and NGOs. Basingstoke: Palgrave, 2018. 74 p.

29. Irrera D. Migrants, the EU and NGOs: The 'Practice' of non-governmental SAR operations. Romanian Journal of European Affairs. 2016. № 16 (3). P. 20-35.

30. Irrera D. NGOs Crisis Management and Conflict Resolution: Measuring the Impact of NGOs on Intergovernmental Organisations. Edward Elgar, Cheltenham, 2013. 192 p.

31. Lazaridis A., Khursheed W. The securitisation of migration in the EU: debates since 9/11. London: Springer, 2015. $247 \mathrm{p}$.

32. Lavenex S., Jurje F. EU/US Migration Policy Towards Emerging Countries: Regulatory Power Reversed? 22 EFA Rev. 2017. № 2 (1). P. 157-175.

33. Léonard S. EU border security and migration into the European Union: FRONTEX and securitisation through practices. European security. 2010. № 19 (2). P. 231-254.

34. Menz A. Stopping, Shaping and Moulding Europe: Two Level Games, Non state Actors and the Europeanization of Migration Policies. JCMS: Journal of Common Market Studies. 2011. № 49 (2). P. 437-462.

35. Meyer C. The quest for a European strategic culture: changing norms on security and defence in the European Union. London: Springer, 2006.

36. Orbie J. Van Elsuwege P., Bossuyt F. Humanitarian Aid as an Integral Part of the European Union's External Action: The Challenge of Reconciling Coherence and Independence. Journal of Contingencies and Crisis Management. 2014. № 22 (3). P. 158-165.

37. Pollak J., Slominski P. Experimentalist but not accountable governance? The role of Frontex in managing the EU’s external borders. West European Politics. 2009. № 32 (5). P. 904-924.

38. Reimann K. D. A view from the top: International politics, norms and the worldwide growth of NGOs'. International Studies Quarterl. 2006. № 50 (1). P. 45-67.

39. Rygiel K., Baban F. The Syrian refugee crisis: The EU-Turkey 'deal'and temporary protection’. Global Social Policy. 2016. № 16 (3). P. 315-320.

40. Risse T. Transnational actors and world politics. Corporate ethics and corporate governance. Berlin: Springer, 2007. P. 251-286.

41. Sterkx S. The external dimension of EU asylum and migration policy: expanding fortress Europe? In Europe's global role: External policies of the European Union. 2008. P. 117-138.

42. Tazzioli M. Border displacements. Challenging the politics of rescue between Mare Nostrum and Triton. Migration Studies. 2016. № 4 (1). P. 1-119. 
43. Trauner F. Asylum policy: the EU's 'crises' and the looming policy regime failure. Journal of European Integration. 2016. № 38 (3). P. 311-325.

44. Warleigh A. Europeanizing'civil society: NGOs as agents of political socialization. JCMS: Journal of Common Market Studies. 2011. № 39 (4). P. 619-639.

Стаття надійшла до редакцї̈ 11.07.2019

Іррера Д.

кафедра політичних та соціальних наук, Університет Катанії

Via Vittorio Emanuele, 49, 95131, Катанія, Італія

\section{НГО ТА ЄС СТОСОВНО УПРАВЛІННЯ СІРІЙСЬКИМИ БІЖЕНЦЯМИ В ТУРЕЧЧИНІ}

\section{Резюме}

Виходячи з припущення, що існують різні підходи до діяльності неурядових громадських організацій (НГО), що впроваджують політику щодо мігрантів та біженців, автор статті намагається відповісти на такі питання: - Які впливи можуть мати НГО на країни-члени та політику ЄС щодо мігрантів та біженців? Чи може такий вплив дати тривалий та усталений досвід в умовах надзвичайних ситуацій? - Чи впливає на даний момент робота НГО в рамках Фонду, поряд 3 міжнародними агенціями та Червоним хрестом, на політику $Є \mathrm{C}$ та відносини з Туреччиною у цій політичній сфері?

Стаття поділена на три частини. В першій недержавні суб'єкти (НГО) аналізуються в рамках теоретичних досліджень з міграції та гуманітарної стратегії. В другій - досліджуються відносини ЄС з Туреччиною через вищезазначені об'єктиви. В третій емпіричні дані про фінансування, що виділяються організацією «Європейські операції з цивільного захисту та гуманітарної допомоги» («European Civil Protection and Humanitarian Aid Operations», ECHO) неурядовим громадським організаціцям, використовуються для оцінки домовленостей та подій. Дані використовуються для оцінки перспектив майбутнього.

В статті зазначається, що події останного десятиліття поставили під сумнів цінності та практику ЄС. Показано, що європейські НГО прагнуть відіграти виконавчу роль у реалізації гуманітарних проектів ЄС для сирійських таборів для біженців у Туреччині. Автор приходить до висновку, що недержавні суб'єкти залишаються важливими, але суперечливими суб'єктами впровадження політики ЄС. НГО мають різні підходи, а їх ідеологічні та політичні розбіжності відбиваються на взаємозв'язку з політичною владою. Автором підкреслено все більш критичне ставлення до відсутності солідарності ЄС, особливо в питаннях втручань, пов'язаних з управлінням надзвичайними ситуаціями, що здійснювалися недержавними операціями SAR. Автором вказано на те, що паралельно практиці, яка, як правило, замінює держави та ЄС, НГО підтримують консолідоване партнерство з ЕСНО. Продемонстровано зростаючу роль недержавних суб'єктів в управлінні чутливими глобальними кризами, такими як міграція та біженці. Ризиком для ЄС визначено упущення шансу керувати кризою як лабораторією та моделлю функціональної координації, яку можна запровадити та закріпити в решті світової системи.

Ключові слова: неурядові організації, мігранти, біженці, Свропейський Союз, Туреччина. 
Иррера Д.

кафедра политических и социальных наук, Университет Катании

Виа Витторио Эмануэле, 49, 95131, Катания, Италия

\section{НПО И ЕС В ОТНОШЕНИИ УПРАВЛЕНИЯ СИРИЙСКИМИ БЕЖЕНЦАМИ В ТУРЦИИ}

\section{Резюме}

Исходя из предположения, что существуют различные подходы к деятельности неправительственных организаций (НПО), внедряющих политику в отношении мигрантов и беженцев, автор статьи пытается ответить на вопросы: - Какие воздействия могут иметь НПО на страны-члены и политику ЕС в отношении мигрантов и беженцев? - Может ли такое влияние дать длительный и устойчивый опыт в условиях чрезвычайных ситуаций? - Влияет ли на данный момент работа НПО в рамках Фонда, наряду с международными агентствами и Красным крестом, на политику ЕС и отношения с Турцией в этой политической сфере?

Статья разделена на три части. В первой части негосударственные субъекты (НПО) анализируются в рамках теоретических исследований по миграции и гуманитарной стратегии. Во второй - исследуются отношения ЕС с Турцией через вышеуказанные объективы. В третьей эмпирические данные о финансировании, выделяемом организацией «Европейские операции по гражданской защите и гуманитарной помощи» («European Civil Protection and Humanitarian Aid Operations», ЕСНО) неправительственным организацицям, используются для оценки договоренностей и событий.

В статье отмечается, что события последнего десятилетия поставили под сомнение ценности и практику ЕС. Показано, что европейские НПО стремятся играть исполнительную роль в реализации гуманитарных проектов ЕС для сирийских лагерей беженцев в Турции. Автор приходит к выводу, что негосударственные субъекты остаются важными, но противоречивыми субъектами внедрения политики ЕС. НПО имеют различные подходы, а их идеологические и политические разногласия отражаются на взаимосвязи с политической властью. Автором подчеркнуто все более критическое отношение к отсутствию солидарности ЕC, особенно в вопросах вмешательств, связанных с управлением чрезвычайными ситуациями, которые осуществлялись негосударственными операциями SAR. Автором указано на то, что параллельно практике, которая, как правило, заменяет государства и ЕС, НПО поддерживают консолидированное партнерство с ЕСНО. Продемонстрирована растущая роль негосударственных субъектов в управлении глобальными кризисами, такими как миграция и беженцы. Риском для ЕC определены упущения шанса управлять кризисом как лабораторией и моделью функциональной координации, которую можно ввести и закрепить в остальной мировой системе.

Ключевые слова: неправительственные организации, мигранты, беженцы, Европейский Союз, Турция. 